\title{
- Build Immunity to Beat Corona Virus Infection
}

\section{Sunita Gupta ${ }^{1 *}$, Sharda Tak², Ashsish Anjankar ${ }^{2}$}

\section{IJCRR}

Section: Healthcare

ISI Impact Factor

(2019-20): 1.628

IC Value (2019): 90.81

SJIF (2020) $=7.893$
'Assistant Professor, Rog Nidan \& Vikrati Vigyan, Datta Meghe, Ayurvedic Medical College Hospital \& Research Centre, Nagpur- 441110, India; ${ }^{2}$ Associate Professor, Department of Biochemistry]awaharlal Nehru Medical College, Datta Meghe Institute of Medical Sciences Sawangi

(Meghe), Wardha-442001, India.

\section{ABSTRACT}

Till there is no permanent solution in form of vaccination to this disease called CORONA VIRUS, we can take precautions and stop it from spreading. Since many people got infected from this virus but those who are safe from infection should take ayurvedic treatment daily to make their immunity strong and enable them to fight with virus strongly.

Key Words: Immunity, Corona, Decoction, Prevention

\section{INTRODUCTION}

At the outset, we must understand Immunity \& Corona. According to Ayurveda, Immunity depends on Ojas, the equilibrium state of Kapha and Udana Vata. There are two terminologies used in Ayurveda to discuss the concept of vyadhiksamatwa (immunity) namely Ojas and Bala. In biology, Immunity is the capability of multicellular organisms to resist harmful microorganisms.

Covid-19 is a disease caused by a new strain of coronavirus. 'CO' stands for Corona, 'VI' for virus and ' $\mathrm{D}$ ' for disease. Let's not fear corona but face it. Because in Ayurveda, various Immunity Promoting Measures have been described. So, we have to build our immunity by taking ayurvedic remedies. It is also said in the textbooks that taking precautions is always better than cure. ${ }^{1,2}$

There is no permanent solution to this disease called coronavirus shortly, but we can take precautions and stop it from spreading. Since many people got infected from this virus but those who are safe from infection should take ayurvedic treatment on daily basis to make their immunity strong and enable them to fight with virus strongly. To overcome this pandemic situation, each and everyone should have strong immunity, and everyone should take precautions even to avoid cough \& cold which arises due to change of weather.

We can keep ourselves healthy by following the proper diet and doing physical activity. The two main objects of Ayur- veda are Caring \& Curing i.e. to take care of a healthy person and curing the disease. If we follow the 1st aim properly by taking care of a person, we can easily help them to avoid un-wellness. ${ }^{3,4}$

\section{REMEDIAL MEASURES}

To boost our immunity, we need to take decoction i.e. "Kadha". The various type of Kadha are described hereunder.

\section{Ayush Kadha I}

5 almonds, 5 black pepper, 1 long pepper (after being kept in water overnight), 5-7 holy basil, 5-7 dry grapes (rinse in hot water and take out the seeds from them).

\section{Ayush Kadha II}

Grind all these and add $100 \mathrm{ml}$ water, 1 cardamom, $1 / 2$ teaspoon turmeric powder, $1 / 2$ teaspoon sugar and boil it properly and afterwards drink it just like tea.

These Kadha can be given to adults @ $1 / 4$ cup and 2 spoons to 5-10-year-old children twice a day.

\section{Guduchi Kadha}

The extract of Guduchi (Tinosphora cardifolia) or holy basil can be used by way of as decoction method. For this, 40-50 gm of Guduchi per person to be boiled with $50 \mathrm{ml}$ of water.

Corresponding Author:

Dr. Sunita Gupta, Assistant Professor, Rog Nidan \& Vikrati Vigyan, Datta Meghe Ayurvedic Medical College Hospital \& Research Centre, Nagpur- 441110, India; Mobile: 9823978098; E-mail: drsunitagupta5@gmail.com

ISSN: 2231-2196 (Print) ISSN: 0975-5241 (Online)

Received: $10.09 .2020 \quad$ Revised: 05.11 .2020

Accepted: 27.12 .2020

Published: 07.05 .2021 


\section{Holi Basil Kadha}

Take 5 to 7 leaves for each person and boil it with water, add sugar or jaggery. It is very useful when a person is suffering from fever or asthma.

\section{Hot Liquids}

All types of hot liquids like Lukewarm water, Milk plain or mixed with turmeric powder, Lemon tea or Ginger Tea etc. are very useful.

\section{Lemon Tea}

Take 5-7 holy basil leaves, 4 black pepper, 1 clove, 1 gm cinnamon, 10-15 gm ginger, and boil all these ingredients with 1 cup of water, then add half lemon before drink it.

\section{Ginger Kadha}

When the person is suffering from cough or cold, take 15-20 gms Ginger extract \& boiled it for few minutes with $100 \mathrm{ml}$ water. Then to add honey or jaggery when the water is lukewarm, then mix it well before drink. This is very useful for a healthy respiratory system.

This Kadha can be given to adults @ $1 / 4$ cup and 2 spoons to 5-10-year-old children twice a day.

\section{Gargle}

When the person is suffering from cough because of allergies, gargle with hot water added with one spoon of rock salt is very useful.

\section{Oil-Massage}

Boil sesame oil and add rock salt therein, then massage it on the chest gently.

\section{Chayvanprash}

Take 10 gm of Chayvanprash daily with 1 glass of plain milk or milk mixed with turmeric. It helps in preventing every type of cough and cold and is very helpful.

\section{Healthy Diet}

It is very important to take care of the whole day's diet as it should be healthy and useful.

- Use fresh and seasonable vegetables.

\section{Not to do}

Don't use or drink cold \& heavy food because they aren't good for health and according to Ayurveda, all of these are cough promoting. 5,6

\section{CONCLUSION}

Ayurveda describes so many dravyas (substance) along with healthy food, to boost up immunity level. By using all these, immunity can be increased to safeguard ourselves from pandemic like Covid-19. Everyone should take necessary precautions, and no one gets afraid of this coronavirus.

\section{Conflict of interest: Nil}

\section{Source of funding: Nil}

\section{REFERENCES}

1. Yadav V, Trikam JI. Acharya Charak Samhita of Agnivesha. Charak and Dridbala. Chaukhamba Sanskrit Sansthan, Varanashi $11^{\text {th }}$ Edition, 2000

2. Astang Sangrah of Vrddha Vaghbhata with Shashilekha Sanskrit. Chaukhamba Series Office, Varanashi $3^{\text {rd }}$ Edition 2012

3. Kaviraj Ambikadutta. Susruta Samhita of Maharsi Susruta edited with Ayured-Tatva-Sandipika Shastri published by Chaukhamba Sanskrit Sansthan, Varanashi $11^{\text {th }}$ Edition, 1997

4. Atharveda Samhita, PrathamaKhanda, ShwetaKushta Naashan Sukta - 23/ 99- 100 .

5. Atharveda Samhita, Divtiya Khanda, Aastrva BhaishjyaSukta 3/ 166- 168.

6. Atharveda Samhita, Divtiya Khanda, Kshetriya Roganashana Sukta $-8 / 195$. 